\title{
Cikkismertetés: A betegségek és sérülések hozzájárulása a várható élettartam-egyenlőtlenségek fokozódásához
}

\author{
Article review: Contributions of diseases and injuries to widening life \\ expectancy inequalities
}

Ismertető: $\quad$ Fromvald Tamás $\square$

Nemzeti Népegészségügyi Központ

Ismertetett cikk: Bennett JE, Pearson-Stuttard J, Kontis $V$ et al. Contributions of diseases and injuries to widening life expectancy inequalities in England from 2001 to 2016: a population-based analysis of vital registration data; Lancet Public Health. 2018 Dec;3(12):e586-e597. doi: $\underline{10.1016 / 52468-2667(18) 30214-7}$

Beküldve: $\quad$ 2019. 03. 04.

doi: $\quad$ 10.24365/ef.v60i2.434

Kulcsszavak: betegség; sérülés; várható élettartam; egyenlőtlenség

Keywords: diseases; injuries; life expectancy; inequalities

\section{HÁTTÉR}

Az egyes társadalmi csoportokban várható élettartam tekintetében Angliában az 1980-as évek óta egyre nagyobb eltérést figyelhetünk meg. Annak ellenére, hogy ezek a folyamatok jól dokumentáltak, kevés információnk van arról, hogy a betegségek és sérülések miatt bekövetkező halálesetek miként befolyásolják a várható élettartamot és mennyiben járulnak hozzá az egyes társadalmi csoportok között tapasztalható élettartam-különbségekhez.

A tanulmány célja a fenti folyamatok vizsgálata volt, illetve a kutatók az eredmények alapján ajánlásokat kívántak megfogalmazni a különböző társadalmi csoportok közötti egészség-egyenlőtlenségek csökkentésére, valamint informálni a döntéshozókat és a civil társadalmat.

\section{MÓDSZER}

Angliában a Nemzeti Statisztikai Hivatal tartja nyilván a népességváltozással kapcsolatos alapvető adatokat. A kutatáshoz a 2001-2016 közötti adatokat használták fel, majd azokat rétegezték nemek és ötévenkénti korcsoportok szerint. Az így kialakított csoportokat a többszörös deprivációs index (Index of Multiple Deprivation, IMD) alapján tíz jövedelmi alcsoportra, decilisekre osztották. A vizsgált időszakban bekövetkezett 7,65 millió halálesetet a betegségek nemzetközi osztályozásának kódjai (BNO) szerint kategorizálták, valamint népegészségügyi és klinikai jelentőségük szerint csoportosítottak. Az okspecifikus halálozási gyakoriságokat Bayes-féle statisztikai szemléletet alkalmazva becsülték meg a nemek, korcsoportok és a többszö- 
rös deprivációs index alapján képzett csoportokban. Minden csoportban kiszámították a születéskor várható élettartamot - ehhez halandósági táblákat használtak -, valamint az egyes betegségekből és sérülésekből származó halálozások hozzájárulását a várható élettartam-réshez a legrászorultabb és a leggazdagabb társadalmi csoportokban - ehhez Arriga-féle módszert használtak.

\section{EREDMÉNYEK}

A leggazdagabb és a leginkább rászoruló csoport várható élettartama közötti különbség nők esetében 2001-ben átlagosan 6,1 év volt (bayesi értelemben vett 95\%-os megbízhatóság: 5,9-6,2), ami 2016-ra 7,7 évre (7,7-8,1) emelkedett. Férfiak esetében is tovább nőtt a várható élettartam különbsége az egyes társadalmi csoportok között: 9,0 évről $(8,8-9,2)$ 9,7 évre $(9,6-9,9)$ emelkedett 2001 és 2016 között.

2011-től a várható élettartam növekedése nők esetében a harmadik, negyedik és az ötödik leginkább rászoruló rétegben megállt, a két leginkább rászoruló decilisben megfordult: 2016-ig a leginkább rászorulóknál 0,24 évvel, azaz mintegy 3 hónappal $(0,10-0,37)$, a második leginkább rászorult rétegnél 0,16 évvel, azaz 2 hónappal $(0,02-0,29)$ megrövidült a várható élettartam.

A 2016-os adatok szerint minden betegségtípusban és minden korosztályban magasabbak voltak a halálozási arányok a legalacsonyabb jövedelmi helyzetű csoportba tartozók körében, mint a legmagasabb jövedelemmel rendelkezők esetében. A várható élettartamban tapasztalható különbségekhez leginkább a következő tényezők járultak hozzá: az 5 éves kor alatti halálozás (főként az újszülöttkori halálesetek), a felnőttkori légzőszervi megbetegedések, szívelégtelenség, valamint tüdőés emésztőszervi daganatok, az idősebb generációt pedig a demencia veszélyezteti leginkább.

2001-től 2016-ig a legtöbb betegségben az életkor szerint standardizált halálozási arányok csökkentek, kivéve a májrákot és a demenciát, amelyek esetében a halálozási arány minden társadalmi csoportban nőtt. 2010 után ugyancsak minden társadalmi csoportban megnőtt a sérülésekből származó halálozási arány.

\section{TANULSÁGOK A HAZAI SZAKEMBEREK SZÁMÁRA}

A felmérésben látható élettartam-változások nemcsak a társadalmi csoportok közötti egészségegyenlőtlenségek növekedését mutatják, hanem azt is, hogy a legalacsonyabb jövedelmi csoportba tartozók várható élettartama csökkent az orvostudomány fejlődése ellenére. A várható élettartamban jelentkező egyenlőtlenségeket olyan betegségcsoportok okozzák, amelyek megelőzhetők és kezelhetők. A tanulmány eredményeit felhasználva hazánkban is elérendő célként határozhatjuk meg, hogy csökkenjen a várható élettartam különbsége a különböző jövedelmi helyzetű csoportokban. 